\title{
Pemberdayaan Masyarakat Model Triple Helix: Pengembangan Desa Wisata Kampung Iklim di Desa Pandowoharjo Sleman Daerah Istimewa Yogyakarta
}

\author{
Bernadus Tresno Sumbodo ${ }^{1}$, Sardi $^{2}$, Sunarya Raharjo ${ }^{3}$, Hermawan Prasetyanto ${ }^{4}$ \\ ${ }^{1,2,3}$ Universitas Janabadra, Jl. TR Mataram, 55-57, Yogyakarta \\ ${ }^{4}$ Perhotelan, STP AMPTA, Jl. Laksda Adisucipto KM 6, Yogyakarta \\ ${ }^{1}$ tresno@janabadra.ac.id \\ ${ }^{2}$ sardi@janabadra.ac.id \\ ${ }^{3}$ sunarya@janabadra.ac.id \\ ${ }^{4}$ hermawan.prasetyanto@yahoo.co.id
}

\begin{abstract}
Abstrak: Pemberdayaan dilakukan dalam kerangka model triple helix, yang terdiri dari akademik, pemerintah, dan komunitas petani daerah urban. Naskah ini merupakan refleksi pelaksanaan program tahun pertama dan kedua 2019-2020 program pengembangan desa mitra (PPDM). Tujuan pengabdian: masyarakat sadar pentingnya melakukan adaptasi terhadap perubahan iklim, menangkap air hujan dan dimasukkan kembali ke dalam tanah, kelompok tani memanfaatkan lahan pekarangan secara optimal untuk pemenuhan kebutuhan pangan keluarga dan menambah pendapatan keluarga. Metode pelaksanaan: pencerahan, pelatihan dan praktek. Kegiatan pengabdian dalam program desa kampung iklim meliputi perancangan instalasi pemanen air hujan (IPAH), sumur resapan dan saluran buntu (rorak), instalasi hidroponik, kandang komunal, pengelolaan sampah, kolam sistem bioflok serta integrasi website. Hasil pengabdian: bertambahnya fasilitas IPAH, sumur resapan, dan rorak, bertambahnya jumlah warga yang panen dan memanfaatkan air hujan, bertambahnya jumlah anggota kelompok tani aktif, perbaikan kualitas kompos, serta terintegrasinya web desa wisata. Melalui program PPDM ini telah dilakukan transfer pengetahuan dan teknologi, menambah wawasan dan memaksimalkan potensi sumber daya alam untuk pengembangan tanaman sayuran di lahan pekarangan, perikanan, peternakan dan pariwisata. Bertambahnya sarana penangkap air hujan sebagai water table yang pada giliranya diharapkan menjadi mata air dan sumber air tanah dangkal untuk mensuplai sumur-sumur warga pada musim kemarau.
\end{abstract}

Kata kunci: desa wisata, kampung iklim, model triple helix, petani urban, sistem bioflok

Abstract: Empowerment is carried out within the framework of the triple helix model, which consists of academics, government, and urban farming communities. This manuscript reflects the implementation of the first and second year of the 2019-2020 partner village development program (PVDP). The purpose of the service: the community is aware of the importance of adapting to climate change, capturing rainwater and putting it back into the soil; farmer groups use their yards optimally to meet family food needs and increase family income. Method of implementation: enlightenment, training and practice. Service activities in the climate village program include designing rainwater harvesting installations (RHI), infiltration wells and dead-end canals (rorak), hydroponic installations, communal cages, waste management, biofloc system ponds and website integration. The service results: increasing RHI facilities, infiltration wells, and rorak, increasing the number of residents harvesting and utilizing rainwater, increasing the number of active farmer group members, improving compost quality, and integrating the tourism village website. Through this PVDP program, knowledge and technology transfer has been carried out, adding insight and maximizing the potential of natural resources to develop vegetable crops in the yard, fisheries, animal husbandry and tourism. The addition of rainwater catching facilities as a water table is expected to become springs and shallow groundwater sources to supply residents' wells during the dry season.

Keywords: biofloc systems, climate villages, triple helix model, urban farming, tourist villages 


\section{PENDAhUluAN}

Awal tahun 2020 dunia dilanda pandemi Covid-19, bersamaan dengan itu program PPDM di Desa Pandowoharjo Sleman Yogyakarta masuk tahun kedua program. Beberapa skema kegiatan harus disesuiakan dengan protokol kesehatan penanggulangan Covid-19. Guncangan akibat Covid-19 tidak hanya terjadi pada sisi konsumsi tetapi juga produksi. Praktik social distancing membuat shock pada sisi produksi yang terlihat dari penutupan pabrik-pabrik dan kegiatan produksi. PHK tidak terelakan, daya beli masyarakat menurun, akibatnya konsumsi barang menurun dan ekonomi terpuruk (Ronal, 2020).

Desa Pandowoharjo merupakan salah satu daerah urban di D.I. Yogyakarta. Sebagian besar mata pencaharian masyarakat adalah petani. Pada masa pandemi Covid-19, banyak warga masyarakat pra sejahtera terdampak secara sosial ekonomi. Sebagian masyarakat, tidak dapat lagi bekerja secara normal bahkan kehilangan sumber penghasilan. Oleh karena itu dibutuhkan sumber penghasilan baru untuk menggantikan sumber penghasilan yang hilang atau berkurang secara finansial. Salah satu sumber penghasilan yang dapat diciptakan adalah memanfaatkan lahan pekarangan dengan budidaya tanaman sayuran, ikan serta ternak.
Secara umum, pemanfaatan lahan pekarangan belum optimal, padahal jika dimanfaatkan secara optimal dengan menanam berbagai jenis tanaman yang sesuai dapat memenuhi ketersediaan pangan keluarga, minimal mengurangi pengeluaran (Yasin \& Kasim, 2018). Terdapat hubungan positif antara variasi pemanfaatan lahan pekarangan dengan ketahanan pangan, semakin tinggi variasi pemanfaatan pekarangan semakin tinggi tingkat ketahanan pangan keluarga. Beberapa kendala pemanfaatan lahan pekarangan, budidaya tanaman harus memperhatikan bagaimana penyiraman dilakukan, budidaya perikanan harus memperhatikan bagaimana ketersediaan air serta beberapa hambatan lain yaitu musim, hama/penyakit, dan teknik pengelolaan (Kuswati, 2016).

Alih fungsi lahan pertanian ke non pertanian, merupakan permasalahan klasik di setiap daerah urban (Sun et al., 2021), berdampak pada produksi pertanian (Domingo et al., 2021). Kontribusi pendapatan usahatani pekarangan menghasilkan 1.20 sampai 9.06 persen. Pendapatan usahatani lahan pekarangan belum memberikan sumbangan cukup besar terhadap total pendapatan keluarga dibandingkan sumber pendapatan dari non pertanian. Hal ini dikarenakan usahatani pekarangan belum menjadi usahatani komersial dan sebagian besar petani (64\%) 
memiliki sumber pendapatan tetap dengan bekerja di sektor non pertanian dan usahatani masih berkonsentrasi pada lahan pertanian sawah (Sumbodo, 2014).

Kampung iklim adalah satu konsep bagaimana masyarakat sadar untuk beradaptasi pada perubahan iklim dengan melakukan berbagai upaya pelestarian sumberdaya alam. Program Kampung Iklim (ProKlim) adalah program berlingkup nasional yang dikelola oleh Kementerian Lingkungan Hidup dan Kehutanan dalam rangka meningkatkan keterlibatan masyarakat dan pemangku kepentingan melakukan penguatan kapasitas adaptasi terhadap dampak perubahan iklim (Ahmed et al., 2021), (Mahmood et al., 2021) dan penurunan emisi gas rumah kaca serta memberikan pengakuan terhadap upaya adaptasi dan mitigasi perubahan iklim untuk meningkatkan kesejahteraan masyarakat (Sileshi et al., 2019), (Ojo et al., 2021). Kampung Iklim adalah lokasi yang berada di wilayah administratif paling rendah setingkat rukun warga atau dusun dan paling tinggi setingkat kelurahan atau desa (Anonimous, 2014), atau wilayah yang masyarakatnya telah melakukan upaya adaptasi dan mitigasi perubahan iklim secara berkesinambungan (Anonimous, 2016a).

Desa Pandowoharjo, mempunyai penduduk 13.164 jiwa, jumlah kepala keluarga 2.635 KK sebagian besar bekerja sebagai petani. Desa Pandowoharjo, merupakan kawasan permukiman yang berada di antara perkotaan dan perdesaan. Desa ini memiliki karakteristik jenis tanah alluvial vulkanik dengan tingkat kesuburan tinggi, kontur tanah dataran ketinggian 243 m dpal., topografi 5\%, jumlah bulan basah rata-rata 6 bulan, curah hujan rata-rata 2116 mm per tahun dan suhu berkisar antara 20,0 33,0 celcius. Luas wilayah Desa Pandowoharjo 727 hektar yang terdiri lahan pertanian sawah 525,48 hektar, tanah pekarangan 104,25 hektar, dan sisanya berupa sungai, jalan dan fasilitas umum 97,27 hektar (Anonimous, 2017).

Desa Pandowoharjo termasuk salah satu desa yang berada di kaki G. Merapi dengan potensi sumber daya alam melimpah, namun karena iklim tidak lagi menentu, maka petani harus mampu beradaptasi dengan perubahan iklim yang terjadi.

Sesuai RPJMDes Pandowoharjo Tahun 2015-2020 (Anonimous, 2015) dalam rangka pengembangan kawasan, Desa Pandowoharjo dikembangkan menjadi desa wisata berbasis pertanian dan desa budaya. Terdapat empat padukuhan (Brayut, Temon, Pajangan, dan Dukuh) telah dicanangkan sebagai desa wisata, dua padukuhan tengah berbenah diri sebagai rintisan desa wisata yaitu Plalangan sebagai desa wisata budaya berbasis ekonomi kreatif dan Karangtanjung sebagai desa wisata kampung iklim 
(Anonimous, 2015). Pencanangan desa wisata tersebut selaras dengan program Pemerintah Kabupaten Sleman sebagaimana tertuang dalam RPJMD Kabupaten Sleman 2016-2021 (Anonimous, 2016b).

Penetapan Padukuhan Karangtanjung sebagai rintisan desa wisata kampung iklim berkat partisipasi aktif masyarakat dalam meningkatkan ketahanan terhadap dampak perubahan iklim, melalui berbagai kegiatan: pengelolaan lahan pekarangan, pengelolaan sampah, pengelolaan mata air, pengelolaan kandang ternak, pengelolaan kolam ikan, pengelolaan energi terbarukan (biogas), serta pengelolaan air hujan.

\section{RUMUSAN MASALAH}

Bencana alam seperti banjir, kekeringan, dan tanah longsor yang terjadi di berbagai daerah salah satu faktor penyebab utamanya adalah akibat erosi dan sedimentasi. Hal ini disebabkan karena pengolahan tanah dan air tidak memperhatikan kaidah konservasi tanah dan air. Untuk mengatasi hal tersebut, penting dilakukan pembinaan dan pendampingan meningkatkan pengetahuan (Ardoin et al., 2020), (Ardoin et al., 2020) dan keterampilan masyarakat dalam konservasi tanah dan air (Kathambi et al., 2020).

Hampir di semua daerah pada musim hujan mengalami banjir dan sebaliknya pada musim kemarau mengalami kekurangan debit air sumur (Wijaya, 2014) untuk kebutuhan hidup sehari-hari. Air hujan dibiarkan jatuh dan mengalir ke sungai kemudian meninggalkan wilayah desa. Sebagian besar masyarakat tidak menyadari pentingnya adaptasi terhadap perubahan iklim yang telah terjadi. Begitu pula hampir di semua daerah urban, dihadapkan pada persoalan keterbatasan lahan subur untuk kegiatan pertanian. Lahan subur banyak berubah fungsi ke non pertanian, sementara petani tidak memiliki kemampuan skill untuk bekerja di luar sektor pertanian. Hal ini menyebabkan petani semakin tertekan karena pendapatan terus berkurang sementara kebutuhan hidup keluarga semakin besar.

Permasalahan yang dicarikan solusi pada pengabdian ini adalah : (i) Bagaimana meningkatkan wawasan kelompok sasaran (mitra) terhadap IPTEK perubahan iklim yang masih rendah, (ii) Bagaimana mengurangi ancaman krisis air tanah, (iii) Bagaimana mengatasi lahan pertanian subur daerah urban terus berkurang dan (iv) Bagimana meningkatkan pendapatan petani terus berkurang, serta beban ekonomi semakin berat.

Tujuan pengabdian ini: Sosialisasi, pelatihan dan pendampingan agar masyarakat sadar pentingnya melakukan adaptasi terhadap perubahan iklim, (ii) Melakukan aksi menangkap 
limpasan air hujan dan dimasukkan kembali dengan menggunakan IPAH, sumur resapan, dan rorak, (iii) Kelompok tani memanfaatkan lahan pekarangan secara optimal sehingga tercipta ketahanan pangan keluarga, dan (iv) Pemenuhan kebutuhan pangan keluarga melalui pengelolaan lahan pekarangan, kelimpahan produksi dijual untuk menambah pendapatan keluarga.

\section{METODE}

Berdasarkan latar belakang permasalahan diatas, perlu pendampingan dalam pengelolaan sumberdaya alam dan pemanfaatan lahan pekarangan bagi kelompok tani. Dengan menggunakan pendekatan triple helix model (Mulyono et al., 2021), tiga unsur terlibat dalam program pemberdayaan ini yaitu pemerintah akademik - kelompok masyarakat. Program pemberdayaan diawali dengan identifikasi permasalahan, kemudian merancang dan menentukan solusi dari permasalahan untuk mengatasi dampak perubahan iklim (krisis air) dan meningkatkan keberdayaan masyarakat.

Sebagai mitra dalam program PPDM ini kelompok tani (Tanjung Lestari dan Andini Mulyo), BUMDesa Amarta, Pokdarwis dan Karangtaruna. Gambar 1. mengilustrasikan kerangka program pemberdayaan skema PPDM di Desa Pandowoharjo Sleman D.I Yogyakarta.

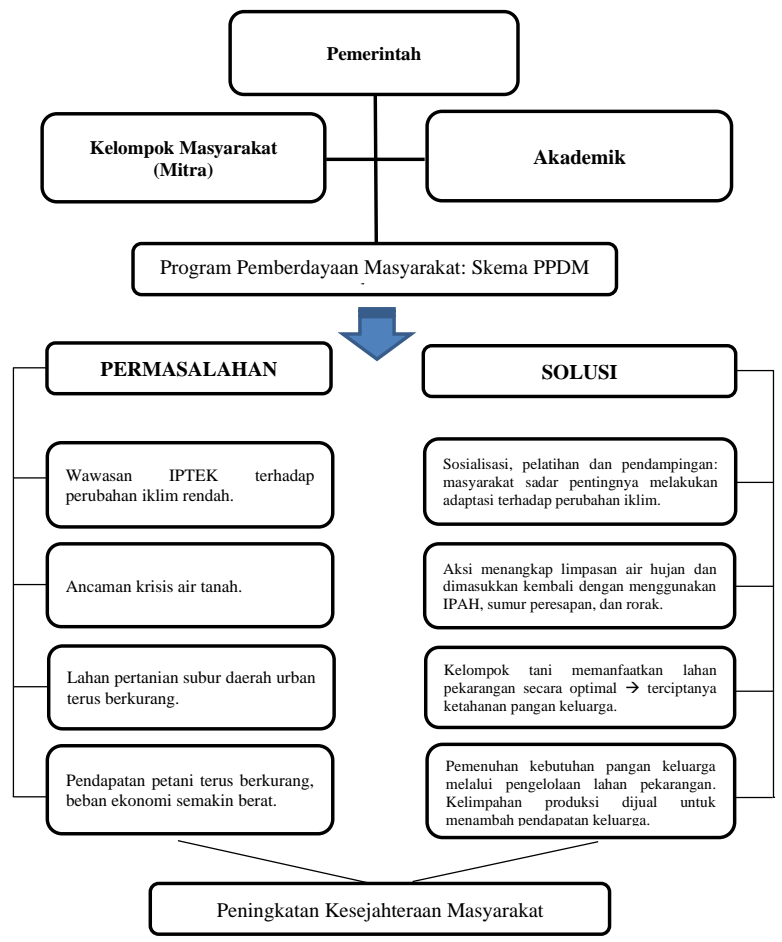

Gambar 1. Kerangka pemikiran

Dalam pengabdian ini, kegiatan pelatihan dilakukan secara terstruktur dengan tiga pendekatan yaitu pencerahan, pelatihan dan praktek. Kegiatan pencerahan dimaksudkan untuk membuka wawasan dan pengetahuan masyarakat (mitra) sekaligus sebagai upaya penyadaran masyarakat terhadap beberapa hal terkait dengan upaya konservasi sumberdaya air dan peningkatan daya dukung lingkungan lainnya. Sedangkan pelatihan dan praktek merupakan dua pendekatan yang saling mendukung satu sama lain dalam upaya meningkatkan pengetahuan dan ketrampilan mitra khususnya terkait dengan teknis budidaya tanaman, perikanan maupun peternakan.

Mitra setelah mengikuti pelatihan dan praktek serta mampu memanfaatkan 
sarana penangkapan air hujan, tugas tim pengabdi berikutnya melakukan pendampingan agar apa yang telah dilatih dan dipraktekkan terus jalan berkesinambungan. Secara singkat, alur proses pelaksanaan pelatihan dan pendampingan secara skematis dapat digambarkan sebagai berikut:

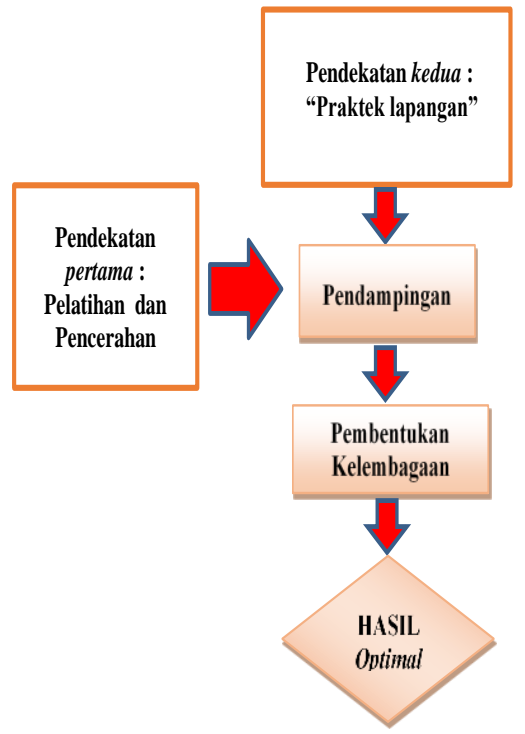

Gambar 2. Metoda pendekatan

\section{HASIL PEMBAHASAN}

\subsection{Instalasi Pemanen Air Hujan (IPAH)}

Prinsip dalam pemanfaatan air hujan adalah air ditabung di musim hujan, untuk dipanen di musim kemarau. Dari instalasi tersebut disalurkan ke tempat yang mudah terjangkau oleh masyarakat untuk dapat digunakan secara bebas seperti untuk cuci tangan, cuci kaki dan sebagainya, sekaligus sebagai bentuk edukasi kepada masyarakat untuk panen dan memanfaatkan air hujan.
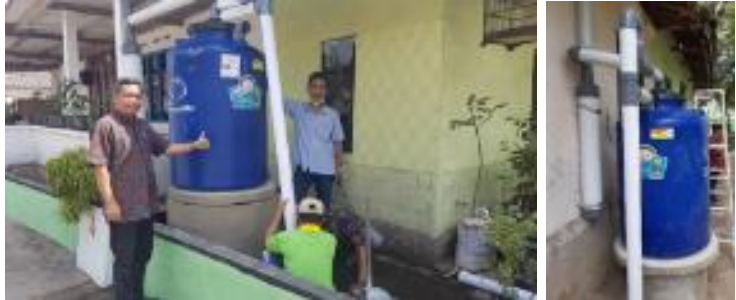

Gambar 3. Instalasi pemanen air hujan

Salah satu rekayasa teknik konservasi air adalah berupa bangunan yang dibuat menyerupai bentuk sumur gali dengan kedalaman 3-4 meter yang berfungsi sebagai tempat menampung air hujan yang jatuh di atas atap rumah atau daerah kedap air dan meresapkannya ke dalam tanah (Dwi T \& R, 2008).

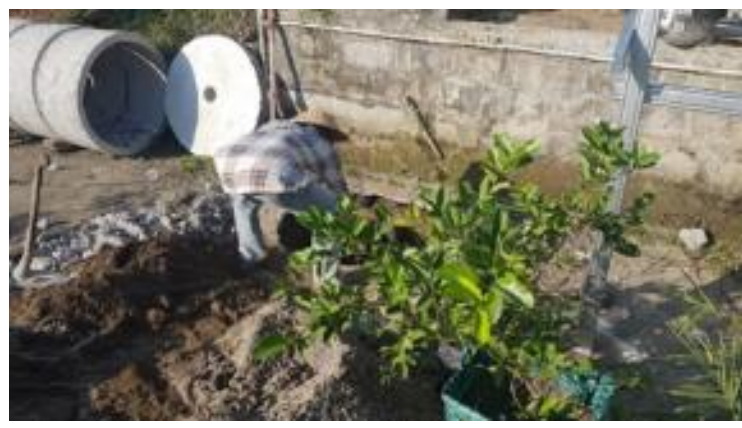

Gambar 4. Sumur resapan

Penentuan lokasi dan desain sumur bangunan resapan mengacu pada SNI No. 03-2453-2002 tentang Tata Cara Perencanaan Sumur Resapan Air Hujan untuk Lahan Pekarangan (Anonimous, 2002). Persyaratan umum pembuatan sumur peresapan: a) resapan air hujan ditempatkan pada lahan yang relatif datar; b) air yang masuk ke dalam sumur resapan adalah air hujan tidak tercemar; c) resapan air hujan harus mempertimbangkan keamanan bangunan sekitarnya; d) memperhatikan 
peraturan daerah setempat; dan e) hal-hal yang tidak memenuhi ketentuan ini harus disetujui instansi yang berwenang.

Saluran buntu merupakan saluran yang buat untuk meresapkan air melalui parit-parit yang didalamnya diberi sumursumur dangkal penampung air. Pembuatan saluran buntu dengan pertimbangan bahwa jika hanya dibangun sumur-sumur resapan individu di beberapa rumah warga maka belum efektif dalam mengurangi debit limpasan yang terjadi di seluruh areal desa.

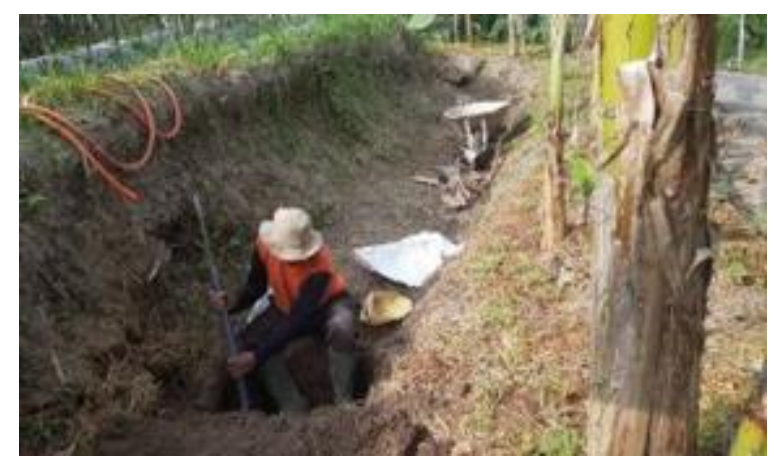

Gambar 5. Saluran buntu (rorak)

\subsection{Pemanfaatan Lahan Pekarangan}

Pada tahun pertama program, telah dilakukan renovasi dan perluasan sarana dan fasilitas green house serta instalasi hidroponik kebun bibit Kelompok Wanita Tani Tanjung Lestari. Renovasi dilakukan dengan mengganti atap dengan UV 14\%, menutup seluruh sayap samping dengan insect net serta penambahan fasilitas instalasi hidroponik di dalamnya. Sebagai penggerak pompa air, hidroponik ini dirancang dengan menggunakan sistem energi solar sell berkekuatan 150W yang mampu menggerakkan tiga pompa sekaligus. Pelatihan hidroponik dilakukan melalui demonstrasi dan praktek secara langsung oleh seluruh anggota kelompok tani. Untuk menjamin keberlanjutan pengelolaan instalasi hidroponik pada tahun kedua program tim pengabdi tetap melakukan pendampingan pengelolaan dan pemanfaatan instalasi hidroponik dengan budidaya berbagai jenis tanaman sayuran.

Metode hidroponik yang dipraktekan dalam program PPDM ini adalah metode Nutrient Film Technique (NFT) yaitu metode hidroponik dengan meletakkan akar tanaman pada lapisan air yang dangkal. (Roidah, 2014). Untuk mensuplai kebutuhan nutrisi tanaman, nutrisi dilarutkan dalam air kemudian disirkulasikan ke daerah perakaran tanaman melalui instalasi hidroponik. Nutrisi untuk budidaya hidroponik harus mengandung nutrisi esensial yaitu berupa unsur makro dan unsur mikro. Unsur makro terdiri dari $\mathrm{C}, \mathrm{H}, \mathrm{O}, \mathrm{N}$, $\mathrm{S}, \mathrm{P}, \mathrm{K}, \mathrm{Ca}, \mathrm{Mg}$. Sedangkan unsur mikro yaitu $\mathrm{Fe}, \mathrm{Mn}, \mathrm{Zn}, \mathrm{Cu}, \mathrm{Co}, \mathrm{B}, \mathrm{Mo}, \mathrm{Cl}$ (Anonimous, 2018).

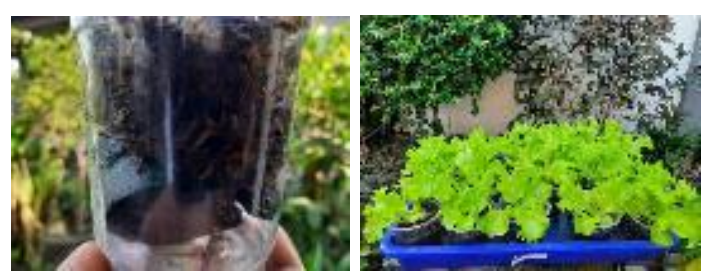

Gambar 6. Media tanam alternatif (tanpa tanah) 


\subsection{Pengelolaan Sampah}

Dalam rangka optimalisai pengelolaan sampah dan sekaligus mendukung pengelolaan lahan pekarangan untuk budidaya ramah lingkungan, dilakukan uji kandungan unsur hara kompos maupun pupuk cair yang dihasilkan BUMDes. Uji laboratorium dilakukan di Balai Pengkajian Teknologi Pertanian (BPTP) Yogyakarta. Hasil uji laboratorium kandungan unsur hara kompos "relatif" baik, dari lima parameter yang diuji, empat diantaranya yaitu C-organik, $\mathrm{C} / \mathrm{N}$ rasio, kadar air, dan $\mathrm{pH}$ telah memenuhi standar baku mutu, ada satu unsur hara makro sedikit dibawah standar baku mutu. Hasil uji laboratorium terhadap kompos menunjukkan parameter unsur makro ( $\mathrm{N}$ total) 1,82 poin, lebih rendah dari standar baku mutu minimal 2 poin. Hasil uji ini diharapkan dapat menyakinkan konsumen bahwa pupuk yang dihasilkan khususnya kompos sudah memenuhi standar, sehingga dapat meningkatkan daya tawar produk. Pupuk yang dihasilkan oleh BUMDes dibeli oleh DLH Kabupaten Sleman, baru sebagian kecil yang dibeli oleh masyarakat luas dengan harga yang relative murah (Rp 1.000 per kg). Terhadap hasil uji laboratorium tersebut, khususnya untuk pupuk kompos diupayakan program pengembangan peningkatan unsur makro dengan penambahan material bahan kompos dari kotoran ternak ayam sehingga mampu meningkatkan kandungan unsur makro. Sedangkan untuk pupuk cair, dari dua parameter utama yaitu unsur makro dan unsur mikro keduanya menunjukkan hasil yang masih dibawah standar baku mutu. Sebagai solusinya dilakukan penambahan material yang dapat meningkatkan unsur mikro dan makro dengan menambahkan urine ternak (kelinci, kambing dan sapi). Dengan jaminan kualitas dan peningkatan mutu kompos, maka pupuk kompos tersebut memiliki daya tawar yang lebih baik dan laku dijual Rp 1.200 per kg.

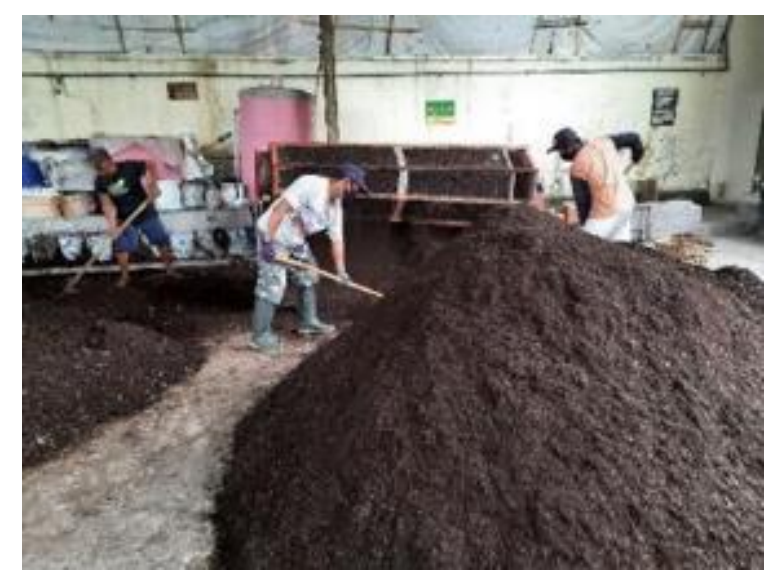

Gambar 7. Pengolahan kompos

\subsection{Pengembangan Desa Wisata}

Sebelum pandemi Covid-19 Desa Pandowoharjo telah cukup dikenal oleh para wisatawan domestik. Orang datang ke Desa Pandowoharjo ada beberapa tujuan: wisata kuliner mengunjungi rumah makan yang sudah sangat terkenal yaitu RM. Jejamuran (dusun Niron), wisata pendidikan (dusun Dukuh) dan wisata budaya (dusun Brayut). Ketiga tujuan wisata tersebut sudah cukup 
dikenal oleh para wisatawan domestik. Kebutuhan dan daya tarik wisatawan dari waktu ke waktu terus meningkat dan berkembang dinamis, maka Desa Pandowoharjo menangkap berbagai peluang tersebut dengan mengembangkan desa wisata kampung iklim di dusun Karangtanjung. Sebelum pandemi Covid-19 kunjungan wisatawan sudah relative banyak datang dari berbagai daerah, baik yang bersifat wisata pendidikan dengan tujuan belajar budaya dan adat isti adat masyarakat pedesaan (oleh siswa-siswi sekolah), wisata kuliner menikmati aneka macam sajian olahan jamur, maupun bentuk-bentuk wisata desa yang lain. Pada masa pandemi Covid19 sejak awal tahun 2020 kunjungan wisata praktis terhenti total, tidak ada wisatawan dating, merupakan pukulan berat bagi pengelola desa wisata di Pandowoharjo. Masuk bulan Agustus 2020, pemerintah D.I. Yogyakarta mulai melonggarkan status darurat Covid-19 sehingga kehidupan ekonomi termasuk dunia kuliner mulai menggeliat kembali. Selama masa pandemi Covid-19 Pokdarwis sebagai rintisan lembaga yang diberikan kewenangan mengelola sektor pariwisata tengah melakukan identifikasi dan pemetaan potensi wisata yang ada di Desa Pandowoharjo. Hasil pemetaan spot-spot potensi desa wisata tersebut dikemas dalam satu website sebagai wadah informasi digital bersama sebagai pintu publikasi dan promosi wisata yang ada di Desa Pandowoharjo dengan domain http://pesonaamarta.com. Potensi wisata di Desa Pandowoharjo bukanlah sebuah destinasi tujuan wisata alam seperti yang ada di beberapa tempat destinasi wisata lainnya. Desa Pandowoharjo tidak memiliki obyek wisata alam, tetapi memiliki potensi pengembangan wisata lain seperti kampung iklim, wisata budaya, wisata pendidikan, wisata kuliner dan sebagainya. Potensi desa wisata di masing-masing dusun itulah yang kemudian dinformasikan dan diintegrasikan dalam satu web bersama pesonaamarta.com.

Tabel 1. Keberdayaan Mitra

\begin{tabular}{lllll}
\hline \multicolumn{3}{c}{ Keberdayaan Mitra } & Hasil \\
\hline Transfer teknologi dan pendampingan & a. Bertambahnya jumlah warga yang \\
kepada masyarakat: sistim panen air & memahami, dan memiliki ketrampilan \\
hujan & & & dalam mensikapi perubahan iklim \\
& & b. Jumlah sarana IPAH, sumur resapan dan \\
& & rorak bertambah 25 unit \\
\hline
\end{tabular}




\begin{tabular}{|c|c|}
\hline Keberdayaan Mitra & Hasil \\
\hline & $\begin{array}{l}\text { c. Jumlah warga yang melakukan panen } \\
\text { dan memanfaatkan air hujan meningkat } \\
(25 \mathrm{KK})\end{array}$ \\
\hline \multicolumn{2}{|l|}{ KWT "Tanjung Lestari” } \\
\hline - Anggota aktif & - 30 orang \\
\hline - Pengetahuan/ ketrampilan & $\begin{array}{l}\text { - } 70 \% \text { anggota memiliki pengetahuan / } \\
\text { ketrampilan vertikurtur dan hidroponik }\end{array}$ \\
\hline - Jumlah produk & - $250 \mathrm{~kg}$ sayuran \\
\hline - Jenis produk & - 25 jenis tanaman sayuran \\
\hline - Jumlah aset & - $\operatorname{Rp} 40.000 .000,0$ \\
\hline \multicolumn{2}{|l|}{ Kelompok Ternak "Andini Mulyo" } \\
\hline - Anggota aktif & - 33 orang peternak \\
\hline - Pengetahuan & $\begin{array}{l}\text { - } 70 \% \text { anggota memiliki pengetahuan dan } \\
\text { kesadaran lingkungan yg bersih dan } \\
\text { sehat }\end{array}$ \\
\hline - Jumlah produk & - 50 ekor per tahun \\
\hline - Jenis produk & - 3 jenis ternak sapi \\
\hline - Jumlah aset & $\begin{array}{l}\text { - } \mathrm{Rp} \mathrm{200.000.000,-} \text { berupa kandang } \\
\text { kelompok }\end{array}$ \\
\hline - Keuntungan & - $\operatorname{Rp} 710.000 .000,-$ \\
\hline \multicolumn{2}{|c|}{ Pokdarwis/Karangtaruna (Budidaya Ikan) } \\
\hline - Pengetahuan/ ketrampilan & - $60 \%$ pengetahuan ketrampilan bioflok \\
\hline - Jumlah produk & - $1.000 \mathrm{~kg}$ lele konsumsi \\
\hline - Jenis produk & - Ikan konsumsi dan benih \\
\hline - Jumlah aset & - $\mathrm{Rp} 35.000 .000,-(20$ kolam terpal $)$ \\
\hline - Keuntungan & - $\quad \operatorname{Rp} 12.000 .000,-$ \\
\hline
\end{tabular}

(Sumbodo et al., 2020)

\subsection{Pengelolaan Kandang Kelompok}

Pengembangan kandang kelompok dimulai sejak 2019 dengan perancangan, pembangunan pondasi hingga konstruksi bangunan, kemudian terhenti cukup lama hingga pertengan tahun 2020 sebagai akibat 
dampak pandemi Covid-19. Kerjabakti warga masyarakat merupakan modal utama swadaya masyarakat dalam mewujudkan bagunan fisik kandang kelompok. Hingga pertengahan 2020 ternak masih berada di kendang individu yang terletak berhimpitan dengan rumah-rumah warga. Ternak itulah yang kemudian dipindah dan disatukan dalam kandang kelompok.

Pengembangan sistem pemeliharaan ternak dari kandang individu menjadi kandang komunal diharapkan lingkungan tempat tinggal menjadi tertata bersih dan sehat. Kandang komunal mampu menampung ternak seluruh warga dusun Karangtanjung sebanyak 33 orang peternak dengan jumlah ternak mencapai 50 ekor.

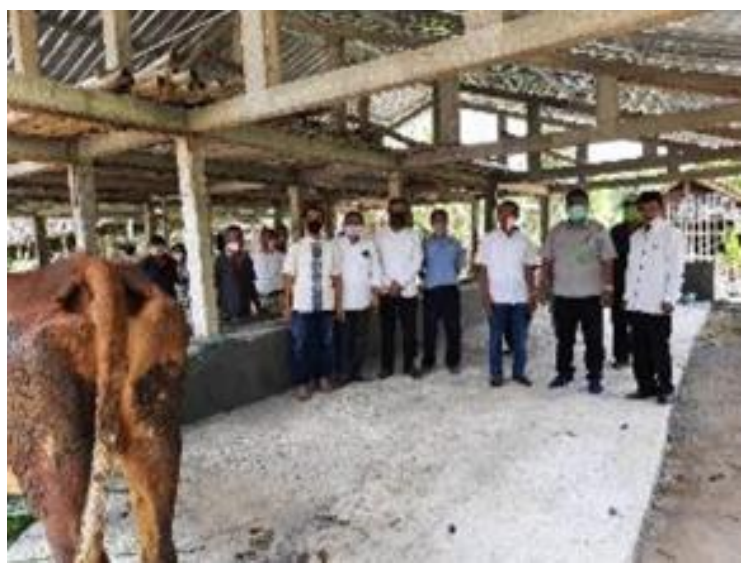

Gambar 9. ProKlim 2020 tingkat nasional

\subsection{Budidaya Ikan sistem Bioflok}

Mensikapi dampak pandemi Covid19, Pokdarwis dan Karangtaruna melakukan alih kegiatan dari aktivitas pariwisata ke produksi ikan. Kolam terpal dibangun untuk produksi ikan lele konsumsi yang dipasarkan kepada pedagang dan konsumen.
Pertengahan 2020, pengelola melakukan diversivikasi usaha berupa pemeliharaan larva untuk memenuhi permintaan pasar benih ikan nila. Pemeliharaan larva hanya membutuhkan waktu lebih cepat ( \pm 1 bulan) dengan tingkat keuntungan lebih tinggi dibandingkan dengan produksi ikan lele konsumsi yang mencapai 3 bulan proses produksi. Kegiatan ini dapat berlangsung berkat kemitraan dengan UPR Budi Fish Farm yang telah lama berproduksi benih ikan dan memiliki jaringan pasar yang luas.

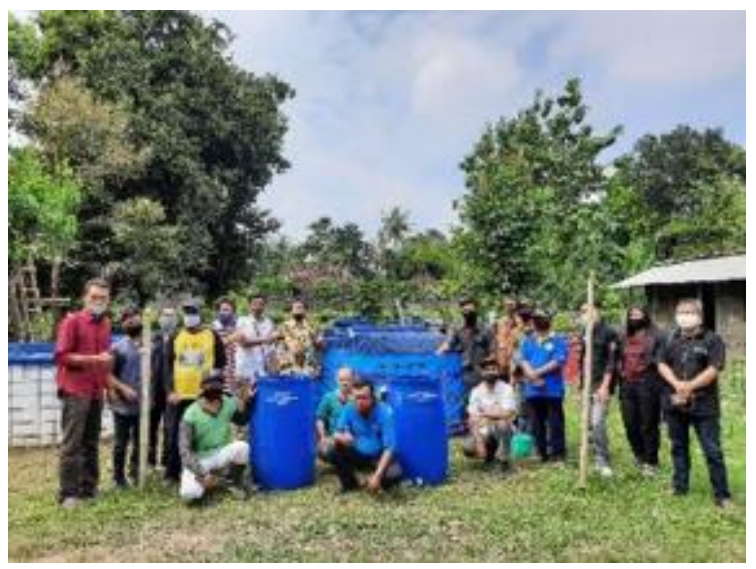

Gambar 8. Pelatihan kolam sistem bioflok

Pada tahun kedua program PPDM ini dilakukan pemberdayaan dan pendampingan masyarakat memelihara lele di kolam drum dan kolam terpal dengan sistem bioflok dengan aplikasi probiotik activator pengurai limbah. Dalam satu drum volume 230 liter, setiap rumah tangga dapat memelihara ikan lele dengan padat tebar 100-200 ekor. Masa pemeliharaan selama tiga bulan sejak pertama kali tebar benih ukuran 7-9 $\mathrm{cm}$ hingga siap panen untuk dikonsumsi (Rizal et al., 2018), (Zidni et al., 2019). Dibawah 
Patria : Jurnal Pengabdian Kepada Masyarakat

ISSN : 2656-5455 (media online) Vol. 3 | No. 2 September 2021

ini secara singkat dapat dilihat analisa usaha kolam drum di lokasi PPDM Pandowoharjo. budidaya ikan lele pada kolam terpal dan

Tabel 2. Analisa Usaha Budidaya Ikan Lele, Desa Pandowoharjo, Sleman 2020

\begin{tabular}{|c|c|c|c|}
\hline \multirow{3}{*}{ No } & \multirow{3}{*}{ Uraian } & \multirow{2}{*}{$\begin{array}{c}\text { Kolam Terpal } \\
\text { D 3m }\end{array}$} & \multirow{2}{*}{$\begin{array}{c}\text { Kolam Drum } \\
\text { V 200lt }\end{array}$} \\
\hline & & & \\
\hline & & $(\mathrm{Rp})$ & $(\mathrm{Rp})$ \\
\hline 1 & Investasi & 14.600 .000 & 5.300 .000 \\
\hline \multirow[t]{4}{*}{2} & Biaya Tetap & & \\
\hline & a. Beban listrik (Rp) & 600.000 & 0 \\
\hline & b. Penyusutan (Rp) & 1.333 .333 & 491.667 \\
\hline & Total (Rp) & 1.933 .333 & 491.667 \\
\hline \multirow[t]{6}{*}{3} & Biaya Variabel & & \\
\hline & a. Benih (Rp) & 2.187 .500 & 1.350 .000 \\
\hline & b. Pakan (Rp) & 11.000 .000 & 1.500 .000 \\
\hline & c. Obat-obatan (Rp) & 2.475 .000 & 1.075 .000 \\
\hline & d. Tenaga Kerja (Rp) & 4.500 .000 & 0 \\
\hline & Total (Rp) & 20.162 .500 & 3.925 .000 \\
\hline 4 & Biaya Total (Rp) & 22.095 .833 & 4.416 .667 \\
\hline 5 & Penerimaan (Rp) & 34.173 .611 & 5.858 .333 \\
\hline \multirow[t]{3}{*}{6} & Keuntungan (Rp) & 12.077 .778 & 1.441 .667 \\
\hline & RCR & 1,55 & 1,33 \\
\hline & PBP & 1,21 & 3,68 \\
\hline
\end{tabular}

Keterangan : Siklus usaha $=3$ bulan

(Sumbodo et al., 2020)

\section{SIMPULAN}

Berdasarkan tujuan dan pelaksanaan pengabdian yang meliputi: adaptasi terhadap perubahan iklim, menangkap air hujan, aktivitas kelompok tani memanfaatkan lahan pekarangan serta pengembangan desa wisata, maka dapat disimpulkan sebagai berikut:
- Rancang bangun sarana pemanenan air hujan berupa IPAH, sumur resapan dan saluran buntu (rorak) sangat penting bagi proses edukasi masyarakat tentang panen dan pemanfaatan air hujan.

- Aksi kelompok masyarakat (mitra) menangkap limpasan air hujan dan 
dimasukkan kembali dengan menggunakan IPAH, sumur resapan, dan rorak merupakan bentuk adaptasi terhadap perubahan iklim.

- Kesejahteraan kelompok masyarakat (mitra) meningkat berkat pemenuhan kebutuhan pangan keluarga melalui pengelolaan lahan pekarangan, dan kelimpahan produksi mampu menambah pendapatan keluarga. Kelompok wanita tani “Tanjung Lestari” sangat terbantu dengan sarana budidaya sayuran sistim vertikultur dan hidroponik, sebagian besar anggota aktif dalam kegiatan kelompok. Kelompok tani ternak "Andini Mulyo" sangat terbantu dengan sarana kandang kelompok, 33 orang anggota kelompok tani ternak dapat memelihara 50 ekor sapi dalam kandang kelompok dan kondisi lingkungan tempat tinggal menjadi bersih dan sehat.

- Pengelola desa wisata (Pokdarwis dan Karangtaruna) tetap eksis pada masa Pandemi Covid-19 dengan melakukan budidaya lele sistem bioflok pada kolam drum dan terpal. Sedikitnya 3 periode dalam satu tahun kolam terpal dengan sistem bioflok dapat digunakan untuk proses produksi dengan keuntungan $\mathrm{Rp}$ 12.000.000,- per bulan.

- Dalam rangka pengembangan desa wisata, program pengabdian ini telah berhasil mengintegrasikan website-website padukuhan dalam satu platform website bersama pesonaamarta.com.

\section{DAFTAR PUSTAKA}

Ahmed, Z., Guha, G. S., Shew, A. M., \& Alam, G. M. M. (2021). Climate change risk perceptions and agricultural adaptation strategies in vulnerable riverine char islands of Bangladesh. Land Use Policy, 103, 105295.

Anonimous. (2002). SNI : 03- 2453-2002: Tata cara perencanaan sumur resapan air hujan untuh lahan pekarangan.

Anonimous. (2014). Peraturan Pemerintah RI Nomor 43 Tahun 2014 tentang Peraturan Pelaksanaan Undang-undang Nomor 6 Tahun 2014 tentang Desa (Nomor 43 Tahun 2014).

Anonimous. (2015). Rencana Pembangunan Jangka Menengah Desa (RPJMDes) Desa Pandowoharjo Tahun 2015-2020.

Anonimous. (2016a). Peraturan Menteri Lingkungan Hidup dan Kehutanan Republik Indonesia No. 84 Program Kampung Iklim.

Anonimous. (2016b). Rencana Pembangunan Jangka Menengah Daerah (RPJMD) Kabupaten Sleman Tahun 2016-2021.

Anonimous. (2017). Pemerintah Desa Pandowoharjo. Monografi Desa Tahun 2017.

Anonimous. (2018). Nutrisi Organik untuk Hidroponik.

http://himatan.ilmutanah.unpad.ac.id

Ardoin, N. M., Bowers, A. W., \& Gaillard, E. (2020). Environmental education outcomes for conservation: A systematic review. Biological Conservation, 241, 108224.

Domingo, D., Palka, G., \& Hersperger, A. M. (2021). Effect of zoning plans on urban land-use change: A multi-scenario simulation for supporting sustainable urban growth. Sustainable Cities and Society, 69. 
Dwi T, S. M., \& R, M. B. (2008). A study on artificial recharge well as a part of drainage system and water supply in UHTM (No. 1; National Seminar on Environment, Development, and Sustainability).

Kathambi, V., Mutie, F. M., Rono, P. C., Wei, N., Munyao, J. N., Kamau, P., Gituru, R. W., Hu, G. W., \& Wang, Q. F. (2020). Traditional knowledge, use and conservation of plants by the communities of Tharaka-Nithi County, Kenya. Plant Diversity, 42(6), 479-487.

Kuswati. (2016). Pemanfaatan pekarangan dalam upaya ketahanan pangan warga desa Karang Gondang Kecamatan Karanganyar Kabupaten Pekalongan. 3.

Mahmood, N., Arshad, M., Mehmood, Y., Faisal Shahzad, M., \& Kächele, H. (2021). Farmers' perceptions and role of institutional arrangements in climate change adaptation: Insights from rainfed Pakistan. Climate Risk Management, 32(February).

Mulyono, A., Ismanto, \& Ika, S. R. (2021). Empowering Coconut Farmer Community for Poverty Alleviation in Kulon Progo, Yogyakarta: A Study of Triple Helix Model. Proceedings of the 3rd International Conference on Banking, Accounting, Management and Economics (ICOBAME 2020), 169, 96100.

Ojo, T. O., Baiyegunhi, L. J. S., Adetoro, A. A., \& Ogundeji, A. A. (2021). Adoption of soil and water conservation technology and its effect on the productivity of smallholder rice farmers in Southwest Nigeria. Heliyon, 7(3), e06433.

Rizal, A., Yustiani, A., Agus Handaka Suryana, A., \& DwiPutro, R. (2018). Analisis komparasi keragaan usaha budidaya ikan lele mutiara (Clarias gariepinus) dengan dan tanpa sistem bioflok. 8(1), 65-70.

Roidah, I. S. (2014). Pemanfaatan Lahan Dengan Menggunakan Sistem Hidroponik. 1(2), 43-50.
Ronal. (2020). Pandemi Covid-19 Akibatkan Meningkatnya Jumlah Pengangguran. https://pasardana.id/news/2020/4/27/ind ef-pandemi-covid-19-akibatkanmeningkatnya-jumlah-pengangguran/

Sileshi, M., Kadigi, R., Mutabazi, K., \& Sieber, S. (2019). Determinants for adoption of physical soil and water conservation measures by smallholder farmers in Ethiopia. International Soil and Water Conservation Research, 7(4), 354-361.

Sumbodo, T. (2014). Analisis Usahatani Pada Lahan Pekarangan. Studi Kasus di Desa Sumbermulyo Kecamatan Bambanglipuro Bantul D.I. Yogyakarta. Program Studi Agribisnis Fakultas Pertanian. Universitas Janabadra: Yogyakarta.

Sumbodo, T., Sardi, Raharja, S., \& Prasetyanta, H. (2020). Lapoan Tahunan: Penguatan Desa Wisata Berbasis Kampung Iklim: Panen dan Pemanfaatan Air Hujan untuk Pengelolaan Lahan Pekarangan menuju Terwujudnya Ketahanan Pangan di Desa Pandowoharjo Kecamatan Sleman D.I. Yogyakarta.

Sun, Q., Qi, W., \& Yu, X. (2021). Impacts of land use change on ecosystem services in the intensive agricultural area of North China based on Multiscenario analysis. Alexandria Engineering Journal, 60(1), 1703-1716.

Wijaya, A. (2014). Potensi air tanah dangkal di daerah kelurahan Kota Baru Kecamatan Pontianak selatan kota Pontianak (Studi Kasus Jalan Dr. Sutomo - Ampera). Jurnal Teknologi Lingkungan Lahan Basah, 2(1), 1-10.

Yasin, S. M., \& Kasim, N. N. (2018). Pemanfaatan Pekarangan Menjadi Kebun Sayur Produktif Di Daerah Pesisir Di Kecamatan Wara Timur. To Maega | Jurnal Pengabdian Masyarakat, $1(1), 1$.

Zidni, I., Andriani, Y., Hasan, Z., \& BSN, S. (2019). Pemanfaatan Pekarangan Rumah Sebagai Penyedia Protein 
Patria : Jurnal Pengabdian Kepada Masyarakat

ISSN : 2656-5455 (media online) Vol. 3 | No. 2 September 2021

Hewani Melalui Budidaya Lele Kolam

Terpal Di Desa Cipacing, Jatinangor,

Sumedang, Jawa Barat. Dharmakarya,

7(4), 248-251. 